\title{
The early changes in retinol-binding protein and prealbumin concentrations in plasma of protein-energy malnourished children after treatment with retinol and an improved diet
}

\author{
By SUZANNE LARGE, G. NEAL AND J. GLOVER \\ Department of Biochemistry, University of Liverpool \\ AND O. THANANGKUL AND R. E. OLSON* \\ Anemia and Malnutrition Research Center, Chiang Mai, Thailand
}

(Received 23 April 1979-Accepted 44 November 1979)

I. Changes in total retinol-binding protein (RBP), the holoprotein (holoRBP) and prealbumin (PA) concentrations have been monitored in plasma of thirty protein- and vitamin A-deficient preschool children from within a few hours up to 7 weeks after treatment with retinol and a good-quality protein diet.

2. The children were classified into groups according to nutritional status as having either kwashiorkor, marasmus-kwashiorkor or marasmus, and given formula diets whose protein and energy contents increased stepwise from I $\mathrm{g}$ and $105 \mathrm{~kJ} / \mathrm{kg}$ body-weight respectively up to $4 \mathrm{~g}$ and $733 \mathrm{~kJ} / \mathrm{kg}$ body-weight after 4 weeks. Retinol was administered in the forms of retinyl palmitate either orally or intramuscularly.

3. PA and total RBP were determined by electroimmunoassay procedures and the holoRBP by its fluorescence after separation from other plasma proteins.

4. RBP in plasma of the vitamin A-deficient child is largely denatured and incapable of binding administered retinol, which must first be taken up by the liver before native holoRBP is released. An increased pool of native apoprotein accumulates in the liver during vitamin A deficiency which is released into plasma quickly after retinol uptake to form peak concentrations of total and holoRBP approximately $3 \mathrm{~h}$ after dosing intramuscularly and $6 \mathrm{~h}$ orally.

5. The accumulated pool of RBP was highest in livers from the marasmus group and lowest in those from the kwashiorkor group, reflecting their relative capacities to synthesize plasma proteins.

6. The mean plasma concentrations of total and holoRBP for the various groups were minimal $24-48 \mathrm{~h}$ after dosing with retinol and then improved almost linearly over the following week.

7. Mean plasma PA concentrations of the various groups on admission were also in order of the severity of their malnutrition. There was little or no change in this protein concentration over the first $24 \mathrm{~h}$ after dosing with retinol, but thereafter the mean values rose almost linearly over 2 weeks. Albumin on the other hand changed little during the first week. The results show that PA is the more sensitive measurement of protein nutritional status.

A number of studies have shown that the plasma concentrations of retinol and its carrier, retinol-binding protein (RBP) and prealbumin (PA) are reduced in protein-energy malnourished (PEM) and vitamin A-deficient preschool children to approximately $25-30 \%$ of the level of normal healthy controls (Smith, Goodman, Arroyave et al. I973; Ingenbleek et al. 1975; Smith, Goodman, Zaklama et al. 1973; Smith et al. 1975; Venkataswamy et al. 1977). After treatment with a massive dose of retinol and a better-quality protein diet the concentrations of the various components of the vitamin A transport system recovered to levels within the normal range after I-2 weeks. None of these studies, however, examined plasma RBP concentration within a few hours after dosing with retinol.

(The nomenclature used in this paper for the various forms of retinol-binding protein is as follows: retinol-binding protein (RBP) is total immunoreactive protein; retinol-binding holoprotein (holoRBP) is native protein with its ligand retinol attached; retinol-binding

* Present address: Department of Biochemistry, School of Medicine, St Louis University, St Louis, Miss. 63104, USA. 
apoprotein (apoRBP) is native protein without retinol and 'apoRBP' is denatured protein incapable of binding retinol.)

Previous studies in the rat showed that vitamin A deficiency alone inhibits the release of RBP from the liver so that the plasma concentration declines to between 25 and $30 \%$ of the normal level while the pool of RBP in the liver increases fourfold (Muto et al. 1972; Smith, Muto et al. 1973). In the protein and vitamin A doubly-deficient rat the pool of accumulated RBP in the liver is smaller than that for the solely vitamin A-deficient animal, as indicated by the lower peak value of plasma retinol-binding holoprotein (holoRBP) reached after its release from the liver within $3-5 \mathrm{~h}$ after the administration of retinol. Again, the further administration of a good-quality protein to the doubly-deficient rat stimulated increased synthesis and release of holoRBP within $24 \mathrm{~h}$ enabling the plasma concentration to be restored to the level found in well-nourished animals (Muhilal \& Glover, 1974). The animal experiments represent the acute situation where deficiency is precipitated quickly. The pattern of recovery in chronically-malnourished children, however, may be different.

It is important to know if native apoprotein (apoRBP) accumulates in chronically vitamin A-deficient children in the same way to be released as holoRBP after dosing with retinol. A temporary increase in the supply of the physiologically-active form of the vitamin would be beneficial for the quicker recovery of the various target tissues. The rate of recovery in the initial period after treatment is critical for the very severely malnourished children whose eyes are affected by corneal xerosis with xerophalmia index $X_{2}-X_{3 A}$ (WHO, I976) and who are liable to become permanently blind if the degradative process in the cornea is not quickly reversed. It has been reported that the partially ulcerated $\left(\mathrm{X}_{3 \mathrm{~A}}\right)$ eyes of some severely-malnourished children sometimes perforate even some hours after being treated with vitamin A and become irreversibly damaged ( $G$. Venkataswamy, personal communication).

It is necessary to know therefore if the supply of holoRBP could be a limiting factor in the healing process within the first few hours after dosing with vitamin A. Plasma concentrations of PA, total RBP and holoRBP have been determined in a group of vitamin Adeficient PEM children admitted to the Anemia and Malnutrition Research Center, Chiang Mai, Thailand at various time intervals after the administration of retinol and an improved dict to check how quickly the plasma proteins in the different clinical groups (kwashiorkor, marasmus and kwashiorkor-marasmus) responded to treatment. In general, the patterns of changes observed in the previously-mentioned plasma proteins were found to be very similar to those for the experimental animals, but their final recovery periods were longer.

\section{METHODS}

\section{Subjects}

Thirty protein- and vitamin A-deficient children whose ages ranged from I4 months to 72 months were medically examined on admission to the Anemia and Malnutrition Research Center, Chiang Mai, Thailand. Details of the vitamin A deficiency signs, particularly those affecting the eyes, were noted, together with the general nutritional status. They were classified as having kwashiorkor, marasmus-kwashiorkor or marasmus using the criteria of McLaren et al. (1967). The visible vitamin A deficiency signs in the eyes varied from none to full keratomalacia $X_{3}$. None of the marasmus group had more severe signs than dryness of the conjunctiva, $X_{1}$, whereas those with marasmus-kwashiorkor and kwashiorkor generally had signs ranging from $X_{1 \text { A }}$ to $X_{3 \text { в }}$ (WHO, 1976). Immediately on admission the children were treated for any mild intercurrent infection and electrolyte imbalance by means of the appropriate minerals, fluids and antibiotics in addition to the improved diet. After a brief settling in period of $24 \mathrm{~h}$, a fasting blood sample approximately $2 \mathrm{ml}$ was taken from 
Table I. The protein $(\mathrm{g})$ and energy $(\mathrm{kJ})$ contents (/ $\mathrm{kg}$ body-weight) of the therapeutic formula diets given to vitamin A-deficient and protein-energy malnourished preschool children

$\begin{array}{ccc}\begin{array}{c}\text { Period after } \\ \text { admission } \\ \text { (d) }\end{array} & \text { Protein } & \text { Energy } \\ 2 & \text { I } & 105 \\ 3 & \text { I } & 210 \\ 5 & \text { I } & 420 \\ 8 & 2 & 420 \\ 10 & 2 & 733 \\ 29 & 4 & 733\end{array}$

an arm vein of each child and transferred to a centrifuge-tube containing heparin as anticoagulant.

\section{Procedures}

Expt I. Four children, one with kwashiorkor, two with marasmus-kwashiorkor, one with marasmus, were each given $30 \mathrm{mg}$ retinol as water-miscible retinyl palmitate (Arovit; Hoffmann-La Roche Inc., Nutley, New Jersey) intramuscularly and a second group of four children, one with marasmus, three with marasmus-kwashiorkor, were given the same dose orally to examine if this route of administration could allow as quick a recovery as the former.

Expt 2. Twenty-two children, eight with kwashiorkor, ten with marasmus-kwashiorkor and four with marasmus, were also given $30 \mathrm{mg}$ vitamin $\mathrm{A}$ each in the form of the watermiscible palmitate intramuscularly.

Diet. All children were placed on a standard formula diet similar to that described by Olson (1975) and containing milk, maize, oil, sucrose and supplementary minerals in gradually-increasing amounts to the level of I g protein and $420 \mathrm{~kJ} / \mathrm{kg}$ body-weight for the first week. After this stabilization period their protein and energy intakes were increased gradually to $4 \mathrm{~g}$ and $733 \mathrm{~kJ} / \mathrm{kg}$ body-weight respectively at day 29 (see Table $\mathrm{I}$ ).

Sampling procedures. During the treatment period small samples of blood $(2 \mathrm{ml})$ were taken at intervals of $\mathrm{I} \cdot 5,3,6, \mathrm{I} 2$ and $24 \mathrm{~h}$ over the first day after dosing and subsequently taken daily for the first week. For the later recovery period samples were taken at 2, 4 and 7 weeks after dosing. The samples were centrifuged at $2000 \mathrm{~g}$ and the plasma frozen and stored at $-20^{\circ}$ until required for analysis. The frozen samples were then sent to Liverpool by air freight in sealed plastic vials packed in an insulated container with solid carbon dioxide. They remained frozen throughout the journey lasting approximately $36 \mathrm{~h}$. They were all analysed for the relatively-labile holoR BP initially and all samples from a particular subject were examined in the same batch.

Values for the normal levels of RBP and PA in plasma of children from the same district of northern Thailand who showed no signs of vitamin A deficiency have been published previously (Smith et al. 1975).

Assay procedures. PA and total immunoreactive RBP were determined by immunoelectrophoresis using the 'rocket' technique of Laurell (1966).

A pool of fresh 'normal' human plasma was used as a substandard in the immunological assay and dispensed into a large number of small plastic vials each containing $0.1 \mathrm{ml}$ plasma. This diluted two-fold provided a solution whose total protein concentration was comparable with that found in PEM children. The concentrations of PA and total RBP in this substandard were assayed against ranges of basic standards prepared by adding to a solution of pure crystalline bovine serum albumin ( $30 \mathrm{~g} / \mathrm{l})$ known amounts of pure PA and RBP isolated 

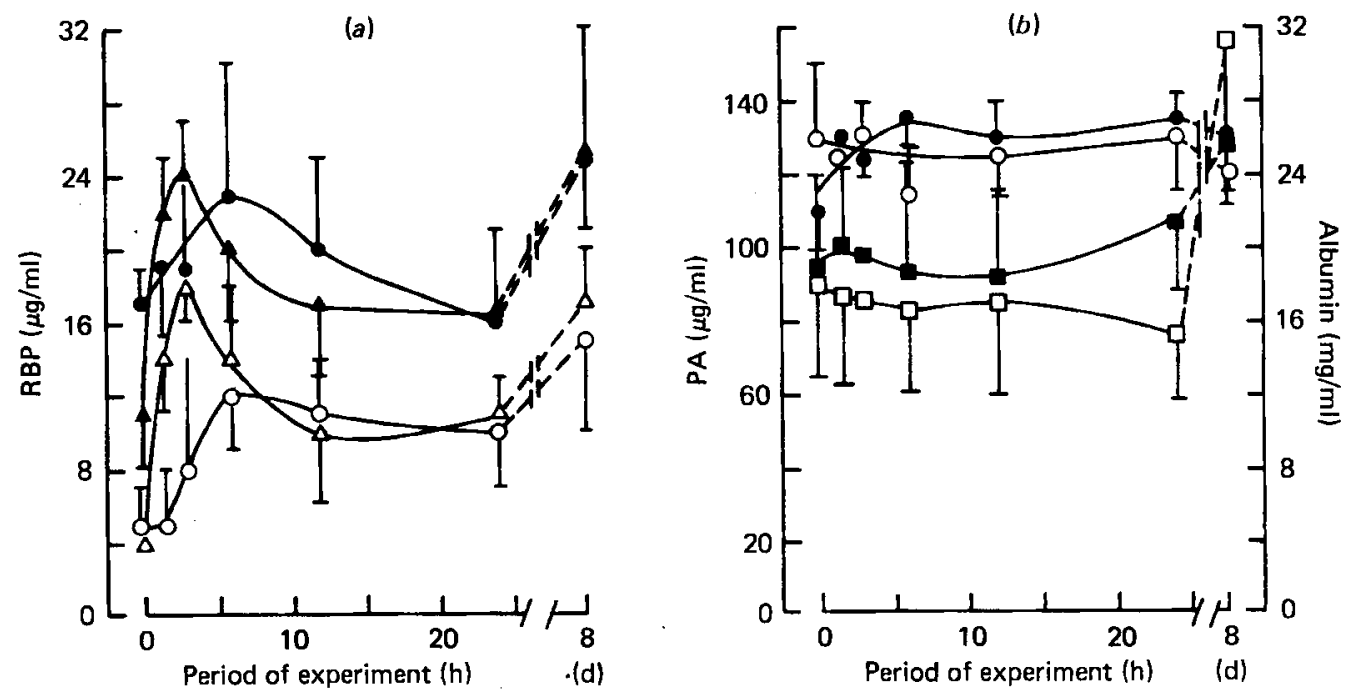

Fig. I. (a) The changes in concentration of retinol-binding holo protein (holoRBP) and total retinol-binding protein (RBP) in plasma of two groups of four protein-energy malnourished and vitamin A-deficient children a few hours after treatment with $55 \mathrm{mg}$ retinyl palmitate administered orally (O-O, holoRBP; $-O$, total RBP) and intramuscularly $(\triangle-\Delta$, holoRBP; $\mathbf{\Delta}-\mathbf{\Lambda}$, total RBP). Both groups were also placed on an improved protein and energy-containing diet.

(b) The concentrations of prealbumin $(\mathrm{PA} ; \mathrm{mg} / \mathrm{ml})(\square-\square)$, orally-treated; $(\square-\square)$, intramuscularly-treated and albumin $(\mathrm{mg} / \mathrm{ml})(\mathrm{O}-\mathrm{O})$, orally-treated $(\mathrm{O}-\mathrm{O})$, intramuscularlytreated in plasma of the same two groups of children. Each point is a mean of 4 values.

(a) In the intramuscularly dosed group, the mean concentrations for holo and total RBP at $3 \mathrm{~h}$ are significantly above those at $12-24 \mathrm{~h}$ with $P<0.025$ and $<0.05$ respectively. In the oral group, the $6 \mathrm{~h}$ value for holoRBP is significantly above the $24 \mathrm{~h}$ concentration. $(P<0.025)$ but the corresponding total RBP values are not significantly different. After $24 \mathrm{~h}$, significant $(P<0.05)$ improvements were observed in both holo and total RBP by day 8 in the two groups.

(b) There was no significant change in the mean values for albumin over the test period. The prealbumin concentration, however, for the two groups is significantly higher by day 8 compared with the level at the outset.

from human plasma and determined spectrophotometrically at $280 \mathrm{~nm}$ using $\mathrm{A}_{1 \mathrm{~cm}}^{\mathrm{x} \%}$ values of 14 (Raz \& Goodman, 1969) and 17.5 (Glover, 1973) respectively for the two proteins.

In these immunoassays it is necessary to match approximately the total protein content of the standards with that present in the unknowns for accuracy. The vials containing the substandard were kept frozen at $-20^{\circ}$ and a separate one was used for each set of assays as required. Where possible all samples of plasma from each subject were examined in duplicate at the same time on two separate agar plates to obviate interassay errors. The coefficient of variation of replicate assays was $<3 \%$ over a wide range of concentrations.

The specific antisera were prepared in the laboratory by injecting the pure proteins $(2-3 \mathrm{mg})$ separately admixed in a slurry $(2 \mathrm{ml})$ with portions of Freund's adjuvant into rabbits in the standard way.

HoloRBP was determined by the procedure previously described (Glover et al. 1974). Albumin was also determined in the samples obtained in Expt. I using the dye-absorption procedure of Bartholomew \& Delaney (I966).

Statistics. The standard errors of the means are given in Table 2 and indicated by bars on the points in the Figures. The level of significance of the changes with time was assessed using the paired $t$ test.

Ethical considerations. The study was approved by the local ethical committee and the 

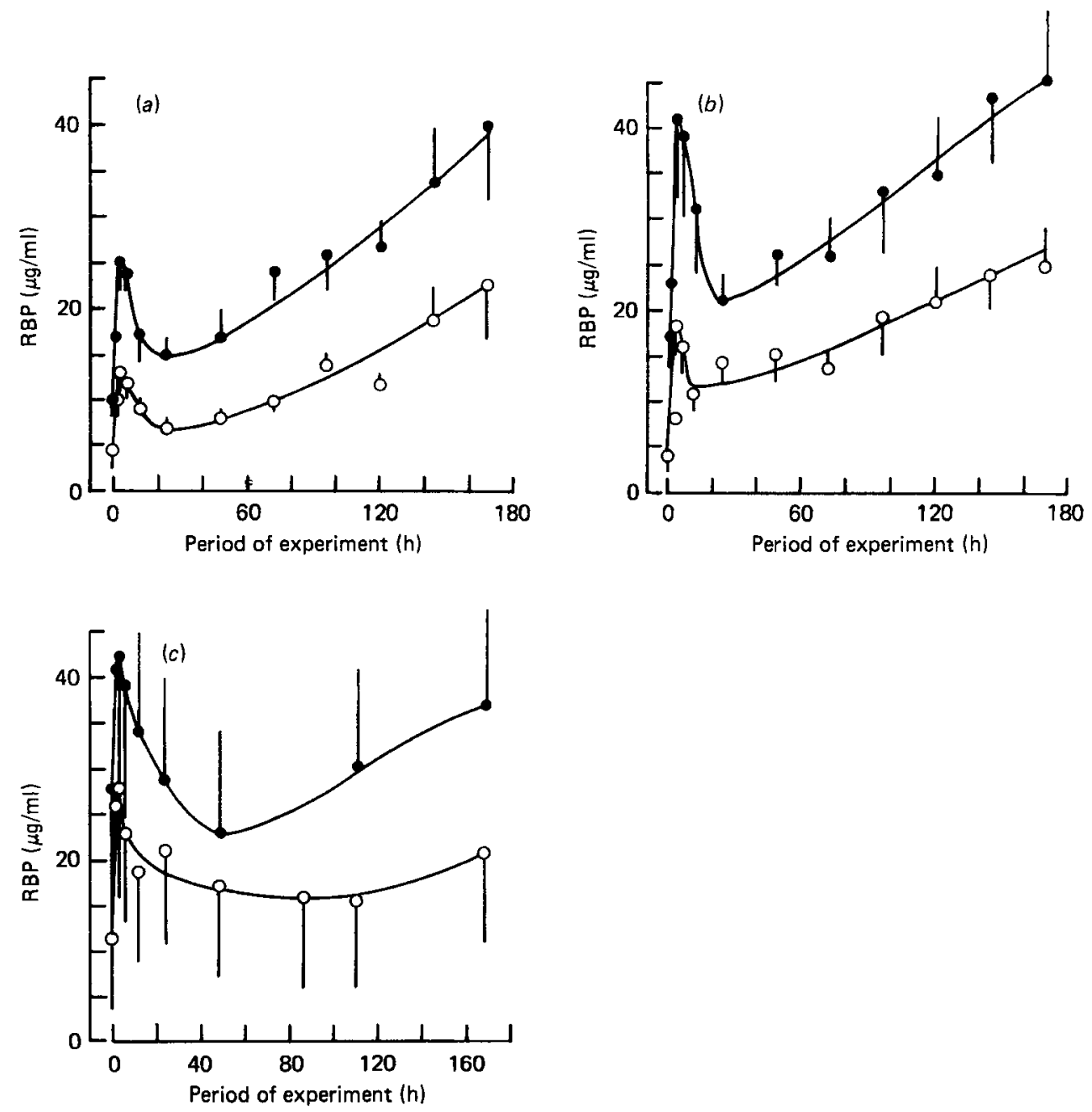

Fig. 2 The variations in concentrations $(\mu \mathrm{g} / \mathrm{ml})$ of retinol-binding holo protein $(O-\bigcirc)$ and total retinol-binding protein (RBP) (-O) in plasma of three groups of protein-energy malnourished and vitamin-A deficient children after administration of $55 \mathrm{mg}$ retinyl palmitate intramuscularly and being placed on an improved protein-quality diet. (a) Eight subjects with kwashiorkor; $(b)$ ten subjects with marasmus-kwashiorkor; $(c)$ four subjects with marasmus.

The mean values for holoRBP and total RBP at the $3 \mathrm{~h}$ peak were significantly higher $(P<0.05)$ than those at outset and $24 \mathrm{~h}$ in all groups with the exception of the $3 \mathrm{~h}$ compared to $24 \mathrm{~h}$ concentration for total RBP in the marasmus group. After $24 \mathrm{~h}$, significant increases in the concentrations of both parameters occurred on day 3 (kwashiorkor group, $P<0.005$ ), day 5 (marasmus-kwashiorkor group, $P<0.05$ ) and on day 7 (marasmus group, $P<0.05$ ).

details of monitoring the progress of the children admitted to the Anemia and Malnutrition Research Center for medical treatment were explained to the parents who gave their written informed consent to it.

\section{RESULTS}

The results for the changes in mean total and holoRBP concentrations which occur in the plasma of the orally- and intramuscularly-treated groups in Expt I are given in Fig. I (a). The very low initial holoRBP and total RBP concentrations in both groups confirm that all 
Table 2. Plasma proteins of three groups of protein-energy malnourished children before and after dietary treatment and receiving single doses of $55 \mathrm{mg}$ retinyl palmitate in Chiang Mai, Thailand

(Mean values with their errors. The children were classified into groups with either kwashiorkor (K), marasmus-kwashiorkor (MK) or marasmus (M) (McLaren et al. 1967))

\begin{tabular}{|c|c|c|c|c|c|c|c|}
\hline \multirow{3}{*}{$\begin{array}{l}\text { Clinical } \\
\text { groups }\end{array}$} & \multirow{3}{*}{$\begin{array}{l}\text { No. of } \\
\text { patients }\end{array}$} & & & \multicolumn{4}{|c|}{ Retinol-binding protein $(\mu \mathrm{g} / \mathrm{ml})$} \\
\hline & & \multicolumn{2}{|c|}{ Prealbumin $(\mu \mathrm{g} / \mathrm{ml})$} & \multicolumn{2}{|c|}{ Total } & \multicolumn{2}{|c|}{ Holo } \\
\hline & & Mean & $\mathrm{SE}$ & Mean & SE & Mean & SE \\
\hline \multicolumn{8}{|c|}{ Before treatment } \\
\hline K & 8 & 37 & 5 & IO & 2 & 4 & 2 \\
\hline $\mathbf{M K}$ & 10 & 59 & 15 & 17 & 3 & 4 & 2 \\
\hline $\mathbf{M}$ & 4 & 126 & 2 I & 28 & I5 & 12 & 8 \\
\hline \multicolumn{8}{|c|}{$\begin{array}{l}\text { After treatment for } \\
\text { I week: }\end{array}$} \\
\hline K & 8 & 87 & 16 & 40 & 8 & 23 & 6 \\
\hline MK & 10 & 97 & 16 & 45 & 9 & 25 & 4 \\
\hline M & 4 & I 52 & 33 & 37 & 5 & $2 I$ & 2 \\
\hline \multicolumn{8}{|c|}{2 weeks: } \\
\hline K & 8 & 117 & 22 & 83 & II & 46 & I I \\
\hline $\mathrm{MK}$ & 10 & 124 & 19 & 79 & 16 & 48 & 10 \\
\hline $\mathbf{M}$ & 4 & I 95 & 55 & 64 & 18 & 37 & 7 \\
\hline \multicolumn{8}{|c|}{4 weeks: } \\
\hline K & 8 & 157 & 30 & 96 & 15 & 55 & 8 \\
\hline MK & 10 & 135 & 17 & 75 & 11 & 48 & 6 \\
\hline $\mathbf{M}$ & 3 & 223 & 42 & 63 & I 2 & 43 & 5 \\
\hline \multicolumn{8}{|c|}{7 weeks: } \\
\hline K & 8 & 176 & 13 & 109 & 9 & 48 & 5 \\
\hline MK & 10 & 131 & 10 & 64 & 4 & 36 & 3 \\
\hline $\mathbf{M}$ & 3 & 186 & 43 & 55 & 16 & 28 & 5 \\
\hline
\end{tabular}

the children were severely vitamin A deficient at the outset. After retinol administration peak values for total and holoRBP in the intramuscular group were reached sooner (within $3 \mathrm{~h}$ ) and were higher than those for the orally-treated group where $6 \mathrm{~h}$ was required for maximal values to be attained. Again the duration of the peak for the intramuscularly-treated group above the minimal concentration at $24 \mathrm{~h}$ was shorter. At $24 \mathrm{~h}$, however, the corresponding values in both groups are very similar. After I week the plasma concentrations of total and holoRBP were restored close to the lower ends of the normal ranges for the age-group; for example $20-30 \mu \mathrm{g} / \mathrm{ml}$ for holoRBP (J. Glover, unpublished observations) and $25-35 \mu \mathrm{g} / \mathrm{ml}$ for total RBP (Smith et al. 1972, 1975) as found in healthy controls (Peterson et al. 1974).

The comparative plasma concentrations of PA and albumin for the orally- and intramuscularly-treated groups are shown in Fig. I $(b)$. No significant changes were observed in either group over the first $24 \mathrm{~h}$, but after 1 week the PA concentrations had commenced to rise above the initial value, whereas there was no detectable response in albumin concentration.

The results for the changes in mean concentration of total and holoRBP in the plasma of. the groups of eight kwashiorkor, ten marasmus-kwashiorkor and four marasmus children in Expt 2 are presented in Fig. 2 ( $a, b$ and $c$ respectively) for the early recovery period up to I week. The corresponding PA results are given in Fig. 3. The values for the later samples taken up to 7 weeks after dosing are set out in Table 2.

$R B P$. It will be seen from Fig. 2 that the kwashiorkor, marasmus-kwashiorkor and marasmus groups in Expt 2 all show immediate increases in plasma holoRBP concentration to 


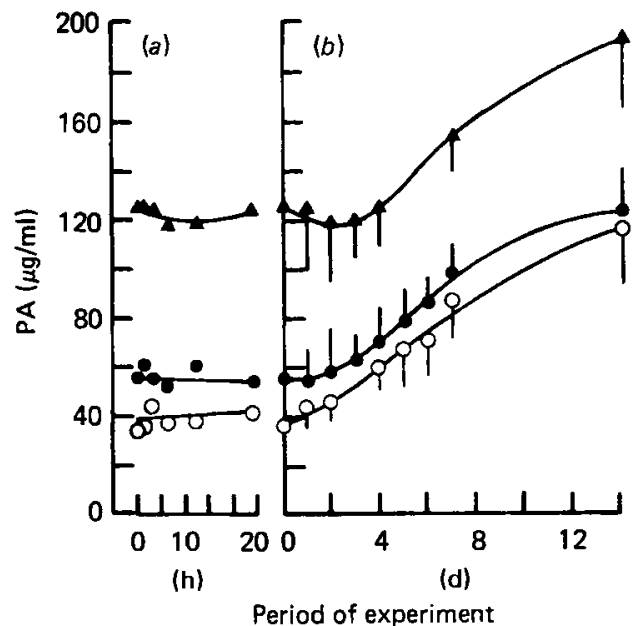

Fig. 3 The variation in prealbumin (PA) concentrations $(\mu \mathrm{g} / \mathrm{ml})$ in plasma of three groups of protein-energy malnourished and vitamin A-deficient children during (a) the first $24 \mathrm{~h}$ and $(b) \mathrm{I}-\mathrm{I} 4 \mathrm{~d}$ after treatment with retinyl palmitate and an improved protein-quality diet. $(\mathbf{\Delta}-\mathbf{\Delta})$ marasmus group; $(\mathrm{O}-\mathrm{O})$ marasmus-kwashiorkor group; $(\mathrm{O}-\mathrm{O})$ kwashiorkor group. Significant increases in prealbumin concentration were observed on day 2 for kwashiorkor group $(P<0.025)$, day 5 for marasmus-kwashiorkor group $(P<0.05)$ and at day 7 in the marasmus group $(P<0.05)$. No significant changes took place in albumin concentrations over the same period.

maxima at $3 \mathrm{~h}(13 \pm 2, \mathrm{I} 8 \pm 3$ and $28 \pm 10 \mu \mathrm{g} / \mathrm{ml}$ respectively) before declining to minimal or plateau levels at $24 \mathrm{~h}(7 \pm \mathrm{I}, \mathrm{I} 4 \pm 2, \mathrm{I} 9 \pm 6 \mu \mathrm{g} / \mathrm{ml}$ respectively) to $48 \mathrm{~h}$. Paired $t$ tests showed that the $24 \mathrm{~h}$ values were significantly different from the $3 \mathrm{~h}$ values $(P<0.025,<0.05$ and $<0.05$ respectively). There was no significant difference between the $24 \mathrm{~h}$ and $48 \mathrm{~h}$ concentrations in each group. Total RBP concentrations followed a similar pattern and maximal values for the 3 groups in the same order were $25 \pm 3,4 \mathrm{I} \pm 9,42 \pm \mathrm{I} 5 \mu \mathrm{g} / \mathrm{ml}$ at $3 \mathrm{~h} \mathrm{com}$ pared with $15 \pm 2,2 \mathrm{I} \pm 3$ and $29 \pm 9 \mu \mathrm{g} / \mathrm{ml}$ plasma at $24 \mathrm{~h}$. The differences were significant $(P<0.025)$ in the kwashiorkor and marasmus-kwashiorkor groups but not in the marasmus group. Again the $24 \mathrm{~h}$ and $48 \mathrm{~h}$ concentrations were similar in each group. In the instance of total RBP the maximum values reached in all groups are approximately 2.5 times the starting concentration and most of these increases appear to be accounted for by native holoRBP released from the liver. The 'apoRBP' circulating in the plasma of the vitamin Adeficient subject is incapable of binding retinol (Glover et al. 1974). Later the plasma concentrations of both holoRBP and total RBP improve gradually to within the normal ranges for the age-group after $7 \mathrm{~d}$ and from Table 2 they can be seen to reach the normal adult levels after $2-4$ weeks (35-70 $\mu \mathrm{g} / \mathrm{ml}$ holoRBP; $50-100 \mu \mathrm{g} / \mathrm{ml}$ total RBP).

$P A$. The initial mean values for plasma $\mathrm{PA}$ concentrations in the kwashiorkor and marasmus-kwashiorkor groups were in the $35-60 \mu \mathrm{g} / \mathrm{ml}$ region and much lower than those for the smaller marasmus groups at $125 \mu \mathrm{g} / \mathrm{ml}$ (Fig. 3). The mean values for the various groups do not change appreciably over the first $24 \mathrm{~h}$. Most of the variations observed were within the experimental error of the assay procedure and any haemodynamic changes which may arise through the restoration of better osmotic conditions with the improved diet. After the second day, however, in the kwashiorkor group and days 3 and 4 in the marasmus-kwashiorkor and marasmus groups respectively there was a uniform increase in the plasma concentration of PA to approximately day I 4 . The increases were significant by day 2 for kwashiorkor $(P<0.025)$, day 5 for marasmus-kwashiorkor $(P<0.05)$ and day 7 for marasmus group $(P<0.05)$. Then the rate of increase declined (Table 2$)$. However, a steady improvement in 
PA values of the marasmus and kwashiorkor groups continued for 4 wecks after which the concentrations tended to level off, but the mean for marasmus-kwashiorkor group showed little change after 2 weeks.

\section{DISCUSSION}

\section{$R B P$}

It has been demonstrated in the vitamin A-deficient rat that the lack of retinol to bind to the native apoRBP causes the pool of it in the liver to increase. The surplus material is immediately released following the administration of retinol, raising the plasma concentration to peak well above the normal value for a few hours (Muto et al. 1972). The extent, however, to which the surplus apoRBP can accumulate is dependent on the capacity of the liver to synthesize the protein from the pool of amino acids supplied mainly from the diet (Muhilal \& Glover, 1974). It is clear from the results in Fig. I (a) that a similar situation obtains for the vitamin A-deficient child. The peaks in plasma holoRBP concentration at 3 and $6 \mathrm{~h}$ after the dosing of these severely-malnourished children with retinol either intramuscularly or orally respectively indicates that some native apoRBP had accumulated in their livers which was quickly released by the vitamin. The quantity, however, was small and really only sufficient to bring the plasma level in the intramuscularly dosed group momentarily to the lower end of the normal range for well-nourished children of the same age-group.

Thus on admission the capacity of the livers in these protein-deficient children to synthesize retinol-binding protein is severely impaired in a similar way to those of experimental rats maintained on a rice diet (Muhilal \& Glover, 1974). The release of RBP into plasma is more clearly seen in the intramuscularly-treated group where a sufficient quantity of retinol reaches the liver simultaneously to bind and release most of the surplus material within $3 \mathrm{~h}$. The more gradual uptake of retinol from the intestine only allows the small increased pool of apoRBP in the liver to be released slowly over $6 \mathrm{~h}$ such that the plasma concentration of holoRBP rises less dramatically forming a low peak or almost a plateau in concentration over the first day. After this small initial surge of holoRBP has been dispersed and utilized the 24 to $48 \mathrm{~h}$ fasting holoRBP level probably reflects capacities of the livers in the different clinical groups to synthesize RBP as shown in Expt 2 (Fig. 2(a-c)). Here retinol was injected intramuscularly so that small surges in plasma concentration of holoRBP and total RBP occur within $3 \mathrm{~h}$ in all groups as for the intramuscularly dosed group in Expt $I$.

The relative sizes of the mean $( \pm \mathrm{SE}) 3 \mathrm{~h}$ peak concentrations $(\mu \mathrm{g} / \mathrm{ml})$ of holoRBP in plasma of the kwashiorkor, marasmus-kwashiorkor and marasmus groups were $13 \pm 2$, I \pm 3 and $28 \pm 10$ respectively. Since the values are directly related to the accumulated surplus of native RBP in the liver before dosing, they also presumably provide some measure of the relative capacities of the livers in the different groups to synthesize the protein at the outset. As might be expected they are in keeping with the clinical classification of the nutritional status. The higher concentrations occur in marasmus cases where liver is less affected than muscle and there is less oedema.

When a comparison is made of the values for total RBP and holoRBP over the $24 \mathrm{~h}$ period in Fig. $2(a-c)$ it can be seen that the increase in plasma concentration of total RBP arises largely from the increase in holoRBP released by the retinol dose. The holoRBP values are probably a little lower than would have been the situation had the plasma samples been analysed completely fresh. Tests carried out in our laboratory on the effect of storage of sterile plasma at $-20^{\circ}$ on holoRBP concentration show that approximately $10 \%$ of retinol is lost over $\mathrm{I} 2$ months. The previously-mentioned samples were kept at $-20^{\circ}$ for approximately 3-4 months over the period of collection and analysis, but no correction has been applied for the small loss of retinol expected $(<\mathrm{I} 0 \%)$. 
The fact that 'apoRBP' was still present in unchanged amounts after the administration of a massive dose of retinol confirms previous observations (Muhilal \& Glover, 1974) that most of it is in denatured form incapable of binding retinol. Even when several of the samples of plasma deficient in holoRBP were incubated with free retinol in vitro none yielded any holoRBP. Since most of the apoRBP accumulated in the livers of vitamin A-deficient subjects is native apoRBP capable of taking up retinol and the material circulating in their plasmas is denatured, the apoRBP entering the circulation from the livers of vitamin Adeficient children must become denatured immediately before or very shortly after its release. Again since protein turnover and metabolism are reduced in malnourished subjects (Muhilal \& Glover, I974; Peterson et al. 1974), the 'apoRBP' probably remains in the plasma longer than it would do in well-nourished children where the amount is generally less than $20 \%$ of the total (Muhilal \& Glover, 1974; Venkataswamy et al. 1977). It was a little surprising however, that after 7 weeks of treatment the gap between total RBP and holoRBP values remained higher than $20 \%$, even allowing for some possible losses of retinol from samples in storage before analyses. This aspect, however, will be discussed more fully in a later paper.

With regard to the rate of improvement in mean plasma holoRBP and total RBP concentrations shown in Fig. $2(a-c)$ and in Table 2, the values for the kwashiorkor and marasmus-kwashiorkor groups were much lower at the outset than that of the marasmus group, but approached the latter value after approximately I week of dietary treatment by which time the plasma holoRBP values were at the lower end of the normal range $(20-30 \mu \mathrm{g} / \mathrm{ml})$. Significant improvements in plasma concentration of holoRBP over the $24 \mathrm{~h}$ minimum value were found on the third day after dosing in the kwashiorkor group $(P<0.005)$ and on the fifth day for the marasmus-kwashiorkor group $(P<0.05)$. The extent of change is less marked in the marasmus group where after the initial surge significant improvement was not observed until 2 weeks later. The greater lag before a definite increase in holoRBP occurred in the latter possibly arose because the starting concentrations in this group were much higher and closer to the normal steady-state range indicating that less damage was sustained by their livers, which would have less need for accelerated catch-up growth.

It required 6 and $4 \mathrm{~d}$ respectively for the plasma holoRBP concentration of the kwashiorkor and marasmus-kwashiorkor groups of children to reach that for the marasmus group level, attained $\mathrm{I}-2 \mathrm{~d}$ after receiving massive doses of retinol. Improvement in holoRBP, however, continued for a further 3 weeks when plasma levels reached the adult range. The high levels probably reflect the increased rate of 'catch-up' growth before the organism settles back to a new steady-state of metabolism supported by the higher plane of nutrition. The results for total RBP (Table 2) follow the same pattern as those of Smith, Goodman, Zaklama et al. (I 973) for total RBP in eight marasmus-kwashiorkor children treated at the Institute of Nutrition of Central America and Panama, Guatemala. The fall in plasma levels of the marasmus-kwashiorkor and marasmus groups after 7 weeks treatment tends to confirm this. In the kwashiorkor group, however, there was no significant difference between the 7 and 4 week concentrations of total RBP, which were significantly higher than those for the other groups at 7 weeks, as if the 'catch-up'-growth period is more protonged in this group.

\section{$P A$}

The mean plasma concentration of PA in the various clinical groups of children on admission to the hospital are in general agreement with those found in other studies on comparable children (Smith, Goodman, Arroyave et al. 1973; Ingenbleek et al. 1975) but the mean value for the small marasmus group in Expt 2 is appreciably higher than that for a similar group of children in northern Thailand (Smith et al. 1975). There is often greater 
variability in the range of values for the latter and the differences probably arise from the small number of samples in both groups.

In both experiments the PA concentration does not change markedly during the first $24 \mathrm{~h}$ after dosing with retinol, showing that its secretion from the liver, unlike that of RBP, is unaffected by vitamin A deficiency. The fact that PA behaves quite differently from that of RBP suggests that the two proteins are secreted independently by the liver so that any complex formation between the two presumably takes place after secretion rather than within the liver itself, as has been suggested previously by Smith, Muto et al. (1973).

PA and RBP respond more quickly to the changes in dietary protein because they have shorter half-lives and smaller metabolic pools than those of albumin. In Expt I, the PA concentration of plasma of both groups of children had increased significantly from 90I $00 \mu \mathrm{g} / \mathrm{ml}$ at the outset to I $30-\mathrm{I} 60 \mu \mathrm{g} / \mathrm{ml}$ after I week, whereas albumin remained unchanged within experimental error in the $2 \cdot 3-2 \cdot 7 \mathrm{mg} / \mathrm{ml}$ range (Fig. I (b)).

In Expt 2 where the children were classified into the different clinical groups, the mean prealbumin concentrations in plasma were $37 \pm 5 \mu \mathrm{g} / \mathrm{ml}$ for kwashiorkor, $59 \pm 15 \mu \mathrm{g} / \mathrm{ml}$ for marasmus-kwashiorkor and $\mathrm{I} 26 \pm 21 \mu \mathrm{g} / \mathrm{ml}$ for marasmus. The first two groups with relatively low outset values showed immediate significant improvement in plasma concentration after day 2 and day 5 respectively whereas no significant increase was detectable in the better marasmus group until $7 \mathrm{~d}$ after administration of the improved diet. However, since this plasma protein shows a steady improvement in concentration over the treatment period and is not subject to possible variations in supply of retinol, it is more useful for measurement of the capacity of the liver to secrete plasma proteins as has been suggested by others (Ingenbleek et al. 1972; Ingenbleek et al. 1975; Olson, 1975). The increase in its concentration over the treatment period from day 3 to day 14 is almost linear in all groups, the response being slightly greater in the marasmus group at $+7 \mu \mathrm{g} / \mathrm{ml}$ per $\mathrm{d}$ compared with $+5 \cdot 5-5 \cdot 8 \mu \mathrm{g} / \mathrm{ml}$ per $\mathrm{d}$ for the marasmus-kwashiorkor and kwashiorkor groups. It is interesting that the PA levels of the kwashiorkor and marasmus-kwashiorkor groups reached the starting level of the smaller marasmus group only after 2 weeks treatment with the improved diet whereas the holoRBP levels were comparable after 3-4 d.

The authors wish to thank the World Health Organisation (grant no. N3/I8I/5I) for their financial support.

\section{REFERENCES}

Bartholomew, R. J. \& Delaney, A. D. (1966). Proc. Aust. Ass. clin. Biochem. 1, 214. Glover, J. (1973). Vitams Horm. 3I, I.

Glover, J., Moxley, L., Muhilal, H. \& Weston, S. (1974). Clinica chim. Acta 50, 371.

Ingenbleek, Y., Van den Schrieck, H. G., De Nayer, P. \& De Visscher, M. (1975). Metabolism $24,633$.

Ingenbleek, Y., Visscher, M. \& De Nayer, P. (1972). Lantet ii, 106.

Laurell, C. B. (1966). Analyt. Biochem. 15, 45.

McLaren, D. S., Pellett, P. L. \& Reed, W. W. C. (I967). Lancet i, 553.

Muhilal, H. \& Glover, J. (1974). Br. J. Nutr. 32, 549.

Muto, Y., Smith, J. E., Milch, P. O. \& Goodman, DeW. S. (1972). J. biol. Chem. 247, 2542.

Olson, R. E. (1975). In Protein-Calorie Malnutrition, p. 275 [R. E. Olson, editor]. New York: Academic Press.

Peterson, P. A., Nilsson, S. F., Östberg, L., Rask, L. \& Valquist, A. (1974). Vitams Horm. 32, 181.

Raz, A. \& Goodman, DeW. S. (1969). J. biol. Chem. 244, 3230.

Smith, F. R., Goodman, DeW. S., Arroyave, G. \& Viteri, F. (1973). Am. J. clin. Nutr. $26,982$.

Smith, F. R., Goodman, DeW. S., Zaklama, M. S., Gabr, M. K., El Maraghy, S. \& Patwardhan, V. N. (1973). Am. J. clin. Nutr. 26, 973 .

Smith, F. R., Suskind, R., Thanangkul, O., Leitzmann, C., Goodman, DeW. S. \& Olson, R. E. (I975). Am. J. clin. Nutr. 28, 732.

Smith, F. R., Underwood, B., Denning, C. R., Varma, A. \& Goodman, DeW. S. (1972). J. Lab. clin. Med. 80,423 .

Smith, J. E., Muto, Y., Milch, P. O. \& Goodman, DeW. S. (1973). J. biol. Chem. 248, 1544.

Venkataswamy, G., Glover, J., Cobby, M. \& Pirie, A. (1977). Am. J. clin. Nutr. 30, 1968.

WHO (1976). Wld Hlth Org. Tech. Rep. Ser. no. 590. 